\title{
Foodborne bacteria in dairy products: Detection by molecular techniques
}

\author{
Nathaly Cancino-Padilla ${ }^{1}$, María Angélica Fellenberg ${ }^{1}$, Wendy Franco ${ }^{2}$, \\ Rodrigo A. Ibáñez ${ }^{1}$, and Einar Vargas-Bello-Pérez ${ }^{1}$ \\ ${ }^{1}$ Pontificia Universidad Católica de Chile, Facultad de Agronomía e Ingeniería Forestal, Departamento de \\ Ciencias Animales. Vicuña Mackenna 4860, Macul, Santiago, Chile. \\ ${ }^{2}$ Pontificia Universidad Católica de Chile, Escuela de Ingeniería, Departamento de Ingeniería Química y \\ Bioprocesos, Departamento de Ciencias de la Salud, Carrera de Nutrición. Vicuña Mackenna 4860, Macul, \\ Santiago, Chile.
}

\begin{abstract}
N. Cancino-Padilla, M. A. Fellenberg, W. Franco, R.A. Ibañez, and E. Vargas-BelloPérez. 2017. Foodborne bacteria in dairy products: Detection by molecular techniques. Cien. Inv. Agr. 44(3):215-229. Because of their unique composition and properties, milk and dairy products represent excellent growth media for many pathogenic microorganisms. Staphylococcus aureus, Salmonella spp., Listeria monocytogenes and Escherichia coli O157:H7 are the most frequent potential pathogens associated with milk or dairy products in industrialized countries and are therefore the main microbiological hazards linked to raw milk and raw cheese. This review summarizes the scientific information about outbreaks related to foodborne pathogens in dairy products and highlights the increasing application of molecular approaches to detect and identify the bacteria responsible for these outbreaks. Molecular techniques have facilitated the rapid detection and identification of foodborne pathogens, which has been crucial for current surveillance and outbreak control.
\end{abstract}

Keywords: Foodborne diseases, food safety, microbiology, omics techniques.

\section{Introduction}

Farm animals represent a major reservoir of pathogens that can be transferred to milk (Arqués et al., 2015). Staphylococcus aureus, Salmonella spp., Listeria monocytogenes, Escherichia coli O157:H7 and Campylobacter are the most frequent potential pathogens associated with milk or dairy products in industrialized countries (Jakobsen et al., 2011) and are the main microbiological

Received June 07, 2017. Accepted September 28, 2017. Corresponding author: evargasb@uc.cl hazards linked to raw milk (Kousta et al., 2010; Yang et al., 2012; Claeys et al., 2013) and raw cheese (Verraes et al., 2015). In addition, as with any food matrix, dairy foods present their own inherent source of inhibitors, such as fat or lipid content, calcium concentration, and the presence of indigenous enzymes, e.g., potential inhibitors, that may have a detrimental influence on the overall integrity of an accurate and sensitive assay (Ozer and Akdemir-Evrendilek, 2014).

In natural conditions, the microbial composition of milk is influenced by different parameters, such 
as the microorganisms present in the teat canal, on the surface of teat skin, or in the surrounding air, as well as the animal's feed, the quality of the water supply, and equipment hygiene (Quigley et al., 2013). For this reason, the detection of pathogens in dairy products can be a challenge and is needed to ensure safety. One of the most important tasks of food safety is the elimination, or at least the reduction, of foodborne pathogens (Giacometti et $a l ., 2013)$. Therefore, it is necessary to find a way to detect pathogens in their early stages of growth in different food products, which could reduce the number of foodborne outbreaks (Pinu, 2016).

\section{Foodborne disease outbreaks related to dairy products}

Because of their unique composition and properties, milk and dairy products represent excellent growth media for many spoilage and pathogenic microorganisms (Nada et al., 2012; Claeys et al., 2013). Table 1 shows a summary of outbreaks associated with the consumption of different dairy products in the world. Additionally, food derived from animals (beef and dairy products, eggs and fish) has been identified as the main vehicle for the transmission of foodborne pathogens to humans (Ahmed and Shimamoto, 2014; Arqués et al., 2015). Additionally, foodborne bacteria can contaminate food products at any point along the production chain: during slaughtering, milking, storage or packaging (Tomat et al., 2016).

Several outbreaks have been associated with the consumption of dairy products, particularly cheese and other ready to-eat foods (Melo et al., 2015). Cheeses are ready-to-eat food products because they do not undergo any further treatment to ensure their safety before consumption. In addition, contamination of cheeses may occur at several stages in the production chain. Therefore, all the information about bacterial characteristics and susceptibility is necessary to prevent contamination of dairy products with pathogens (Kousta et al., 2010).
Reports from developed countries indicated that milk and dairy products are implicated in 1-6\% of the total bacterial foodborne outbreaks (Ahmed and Shimamoto, 2014), with $39.1 \%$ attributed to milk, $53.1 \%$ to cheese and $7.8 \%$ to other milk products (Claeys et al., 2013). In 2013, 2.14\% of foodborne outbreaks were attributed to the consumption of cheese and dairy products (11 and 7 outbreaks, respectively) in Europe (Dalzini et al., 2016).

The most common source of reported outbreaks in the USA has historically been raw (unpasteurized) milk (Taylor et al., 2013). In their study, Bianchi et al. (2013) concluded that unpasteurized milk can be a vehicle for a variety of microorganisms (Listeria spp., Salmonella, and Campylobacter) and that outbreaks related to cheeses made with unpasteurized milk are also common (Gould et al., 2014). The development of a disease after consumption of contaminated dairy products made from raw milk depends on several factors, such as the pathogenicity of the bacteria strain, the number of ingested microorganisms, the physiological state of the microorganism, and the health condition of the consumer at the moment of ingestion (Verraes et al., 2015).

\section{Bacteria involved in dairy product contamination}

Staphylococcus aureus, Salmonella spp., Listeria monocytogenes and Escherichia coli $\mathrm{O} 157: \mathrm{H} 7$ are the most frequent potential pathogens associated with milk or dairy products in industrialized countries (Jakobsen et al., 2011) and are therefore the main microbiological hazards linked to raw milk (Kousta et al., 2010; Yang et al., 2012; Claeys et al., 2013) and raw cheese (Verraes et al., 2015). Raw milk provides a potential growth medium for the development of bacteria that can be controlled or destroyed through the pasteurization process (Arqués et al., 2015). However, the number of people consuming unpasteurized products continues to increase all over the world due to a growing demand for natural and unprocessed foods (Fusco and Quero, 2014). 
Table 1. Summary of outbreaks associated with the consumption of different dairy products in the world

\begin{tabular}{|c|c|c|c|c|c|}
\hline Year & Country & Product involved & Pathogen & Cases & Reference \\
\hline \multicolumn{6}{|l|}{ North America } \\
\hline 1998 & Canada & Cheese & Salmonella enterica & 80 & Ahmed et al., 2000 \\
\hline $1998-2011$ & United States & $\begin{array}{c}\text { Cheese } \\
\text { (Unpasteurized milk) }\end{array}$ & $\begin{array}{c}\text { Salmonella } \\
\text { Listeria monocytogenes } \\
\text { Escherichia coli }\end{array}$ & $\begin{array}{c}13 \\
4 \\
4\end{array}$ & Gould et al., 2014 \\
\hline 2002 & Canada & Soft Ripened Cheese & Listeria monocytogenes & 130 & McIntyre et al., 2015 \\
\hline 2005 & United States & Raw milk & $\begin{array}{c}\text { Escherichia coli } \\
\text { O157:H7 }\end{array}$ & 18 & Denny et al., 2008 \\
\hline 2007 & United States & Pasteurized Milk & Listeria monocytogenes & 5 & MMWR, 2008 \\
\hline 2008 & Canada & Cheese (Pasteurized milk) & Listeria monocytogenes & 38 & Gaulin et al., 2012 \\
\hline $2001-2010$ & United States & Raw milk & $\begin{array}{l}\text { Campylobacter spp. } \\
\text { STEC } \\
\text { Salmonella spp. }\end{array}$ & $\begin{array}{c}407 \\
31 \\
39\end{array}$ & Robinson et al., 2014 \\
\hline 2010 & United States & $\begin{array}{c}\text { Gouda cheese } \\
\text { (Unpasteurized milk) }\end{array}$ & $\begin{array}{c}\text { Escherichia coli } \\
\text { O157:H7 }\end{array}$ & 19 & McCollum et al., 2012 \\
\hline $2010-2012$ & United States & Raw milk & $\begin{array}{c}\text { Campylobacter spp. } \\
\text { STEC }\end{array}$ & $\begin{array}{c}40 \\
8\end{array}$ & Mungai et al., 2015 \\
\hline 2012 & United States & Ricotta salata cheese & Listeria monocytogenes & 6 & Heiman et al., 2016 \\
\hline 2013 & Canada & $\begin{array}{c}\text { Gouda cheese } \\
\text { (Unpasteurized milk) }\end{array}$ & Escherichia coli 0157 & 29 & Gill and Oudit, 2015 \\
\hline 2014 & United States & Ice cream & Listeria monocytogenes & 2 & Rietberg et al., 2016 \\
\hline 2015 & United States & Ice cream & Listeria monocytogenes & 4 & Pouillot et al., 2016 \\
\hline \multicolumn{6}{|l|}{ Europe } \\
\hline 1996-1997 & United Kingdom & Formula-dried milk & Salmonella enterica & 17 & Threlfall et al., 1998 \\
\hline 1997 & France & $\begin{array}{c}\text { Morbier cheese } \\
\text { (Unpasteurized milk) }\end{array}$ & Salmonella enterica & 113 & De Valk et al., 2000 \\
\hline 1998-1999 & Finland & Butter & Listeria monocytogenes & 25 & Lyytikäinen et al., 2000 \\
\hline $1997-2001$ & France & $\begin{array}{l}\text { Cheese (Unpasteurized } \\
\text { milk) }\end{array}$ & Staphylococcus aureus & 70 & Kérouanton et al., 2007 \\
\hline $2004-2005$ & France & Powdered Infant Formula & Salmonella enterica & 136 & Brouard et al., 2007 \\
\hline $2005-2007$ & Netherlands & Raw milk & Campylobacter jejuni & 38 & Heuvelink et al., 2009 \\
\hline 2006 & Netherlands & Hard cheese & $\begin{array}{l}\text { Salmonella } \\
\text { Typhimurium }\end{array}$ & 38 & Van Duynhoven et al., 2009 \\
\hline $2006-2007$ & France & $\begin{array}{l}\text { Cheese (Unpasteurized } \\
\text { milk) }\end{array}$ & Salmonella enterica & 23 & Dominguez et al., 2009 \\
\hline $2006-2007$ & Germany & Cheese (Pasteurized milk) & Listeria monocytogenes & 34 & Koch et al., 2010 \\
\hline 2007 & Austria & $\begin{array}{l}\text { Milk, cacao milk or vanilla } \\
\text { milk }\end{array}$ & Staphylococcus aureus & 166 & Schmid et al., 2009 \\
\hline 2008 & Spain & Infant Formula & Salmonella kedougou & 21 & Rodríguez-Urrego et al., 2010 \\
\hline 2009 & Austria & Quargel cheese & Listeria monocytogenes & 25 & Fretz et al., 2010 \\
\hline 2009 & Germany & Quargel cheese & Listeria monocytogenes & 8 & Fretz et al., 2010 \\
\hline 2009 & Czech Republic & Quargel cheese & Listeria monocytogenes & 1 & Fretz et al., 2010 \\
\hline 2009 & France & $\begin{array}{l}\text { Soft cheese (Unpasteurized } \\
\text { milk) }\end{array}$ & Staphylococcus aureus & 23 & Ostyn et al., 2010 \\
\hline 2012 & Portugal & Cheese (Pasteurized milk) & Listeria monocytogenes & 30 & Magalhães et al., 2015 \\
\hline 2012 & Spain & $\begin{array}{l}\text { Latin-style fresh cheese } \\
\text { (Pasteurized milk) }\end{array}$ & Listeria monocytogenes & 2 & De Castro et al., 2012 \\
\hline
\end{tabular}




\begin{tabular}{|c|c|c|c|c|c|}
\hline Year & Country & Product involved & Pathogen & Cases & Reference \\
\hline 2013 & Germany & Ice cream & Staphylococcus aureus & 13 & Fetsch et al., 2014 \\
\hline 2014 & Switzerland & $\begin{array}{l}\text { Soft cheese (Unpasteurized } \\
\text { milk) }\end{array}$ & Staphylococcus aureus & 14 & Johler et al., 2015 \\
\hline 2014 & Finland & Raw milk & $\begin{array}{c}\text { Yersinia } \\
\text { pseudotuberculosis }\end{array}$ & 43 & Pärn et al., 2015 \\
\hline \multicolumn{6}{|l|}{ Asia } \\
\hline 2000 & Japan & Reconstituted milk & Staphylococcus aureus & 13420 & Asao et al., 2003 \\
\hline \multicolumn{6}{|c|}{ South America } \\
\hline 2006 & Argentina & Cream & Staphylococcus aureus & 53 & López et al., 2008 \\
\hline 2007 & Paraguay & Ultrapasteurized milk & Staphylococcus aureus & 400 & Weiler et al., 2011 \\
\hline 2008 & Chile & Brie and Camembert cheese & Listeria monocytogenes & 165 & Montero et al., 2015 \\
\hline
\end{tabular}

†STEC: Shiga toxin-producing Escherichia coli

Outbreaks due to cheese made from unpasteurized milk are often caused by Salmonella (34\%), Campylobacter (26\%), Brucella (13\%), and Shiga toxin-producing Escherichia coli (11\%) (Gould et al., 2014). Listeria is killed by pasteurization, and outbreaks of this bacterial strain have rarely been associated with pasteurized dairy products, including cheese (Koch et al., 2010). These foodborne bacteria are of concern for the dairy industry because they have been identified in different dairy products and have been implicated in outbreaks (Kousta et al., 2010; Yang et al., 2012; Claeys et al., 2013; Ricci et al., 2013; Robinson et al., 2014; Tayel et al., 2015; Pouillot et al., 2016).

Listeria monocytogenes has been involved in numerous outbreaks occurring after consumption of contaminated milk and dairy products throughout the world (Wang et al., 2015; Dalzini et al., 2016). In 2015, dairy products were identified as the main sources of listeriosis (Quero et al., 2014; Jackson et al., 2016). Raw milk can be contaminated with Listeria monocytogenes from unclean equipment during milking, during storage in bulk tanks or during transport to the cheese processing plant, where hygienic control measures may not be adequate (Melo et al., 2015). Because of its high case-fatality rate, listeriosis is, after salmonellosis, the second most frequent cause of foodborne infection-related deaths in Europe (Arqués et al., 2015; Dalzini et al., 2016). However, outbreaks from Listeria monocytogenes are not common compared with those caused by pathogens such as Salmonella (Todd and Notermans, 2011).

Staphylococcus aureus is a ubiquitous pathogen; thus, the sources of this bacteria for dairy products contamination are diverse (Rosengren et al., 2010). This bacterium is commonly found in a wide variety of mammals and birds and can be transferred to food mainly by dairy animals that have mastitis and by human carriers during food processing (Hennekinne et al., 2012). Contamination of Staphylococcus aureus can have a broad occurrence in raw dairy products, with frequencies between 5 and 100\% in cheeses (Verraes et al., 2015). The number of Staphylococcus aureus in raw milk or other dairy products needs to be less than $10^{4} \mathrm{CFU} \mathrm{g}^{-1}$, according to the US FDA regulations (Yu et al., 2016). During the manufacture of cheese, natural staphylococcal contamination is a minor component of the total microbial population, and the initial Staphylococcus aureus contamination is usually below $10^{3} \mathrm{CFU}$ $\mathrm{ml}^{-1}$ of raw milk (Duquenne et al., 2010). Foods of animal origin with high protein contents such as milk and dairy products, meat, meat products, salads and bakery products favor the growth of bacteria, and this type of food has been frequently 
incriminated in Staphylococcus aureus outbreaks (Fetsch et al., 2014). This bacterium can grow in an extensive range of temperatures, $\mathrm{pH}$ values, sodium chloride concentrations and water activity and it can also produce staphylococcal enterotoxins, which are responsible for staphylococcal food poisoning (Schelin et al., 2011).

Staphylococcus aureus is present in raw materials and food and can be inactivated with heat treatment, but enterotoxins are heat resistant and may persist in food even after heat treatment. Staphylococcal enterotoxins are active even after boiling for $30 \mathrm{~min}$ and may remain stable at 121 ${ }^{\circ} \mathrm{C}$ for $28 \mathrm{~min}$ (Necidova et al., 2016). Minimum pasteurization treatments are based on European legislation, which set the heat treatment at $72{ }^{\circ} \mathrm{C}$ for $15 \mathrm{~s}$ or $63{ }^{\circ} \mathrm{C}$ for $30 \mathrm{~min}$. High-temperature pasteurization is defined as heat treatment of milk at not less than $85{ }^{\circ} \mathrm{C}$. In addition, in the Chilean food regulations (Reglamento Sanitario de los Alimentos), dairy products are treated at ultra-high-temperatures (UHTs) $130^{\circ} \mathrm{C}$ and 145 ${ }^{\circ} \mathrm{C}$ for 2 or $4 \mathrm{~s}$ to ensure inactivation of bacteria and toxins.

Salmonella spp. is the most frequent cause of food-borne outbreaks, and human salmonellosis is the second most frequently reported zoonosis in the European Union (Wuyts et al., 2013). Milk is a food that has a high chance of contamination by Salmonella spp. (Riyaz-Ul-Hassan et al., 2013), mainly before leaving the farm, usually because of fecal contamination during the milking process (Ahmed and Shimamoto, 2014). Additionally, Salmonella spp. can be transmitted to humans via the consumption of contaminated dairy products (Vignaud et al., 2017), especially unpasteurized or insufficiently pasteurized milk and cheeses, which cause outbreaks of salmonellosis in humans (De Valk et al., 2000; Ahmed and Shimamoto, 2014). Finally, the main reservoirs of Shiga toxin-producing Escherichia coli are ruminants, contaminating milk through subclinical mastitis or feces, and the bacteria can persist in milking equipment (Arqués et al., 2015).

\section{Foodborne bacteria detection}

The detailed characterization of isolates is critical for the investigation of common outbreak sources in order to identify the source, implement control measures and/or take steps to remove the implicated food from the market place (Bopp et al., 2016).

\section{Conventional methods}

Traditional methods for the detection of bacterial pathogens in foods have been widely used because they are sensitive and inexpensive and can give both qualitative and quantitative information on the number and the nature of the microorganisms present in the food sample (Zhao et al., 2016). The conventional methods for detection of these pathogens involve identification and confirmation based on culturing on selective media along with biochemical tests and immunological assays (Quigley et al., 2013). These methods are standard methods; however, they are extremely laborious, time consuming (requiring several days), and often inconclusive (Singh et al., 2011; Chen et al., 2015; Bopp et al., 2016; Yu et al., 2016). For these reasons, there is an increasing demand for more rapid methods of foodborne pathogen detection (Zhao et al., 2014), in order to complement or replace the traditional microbial culture procedures with more advanced, sensitive, and rapid microbial detection methods.

\section{Molecular genetic techniques}

Due to their limitations, conventional methods are now giving way to molecular diagnostic methods based on DNA analysis, such as polymerase chain reaction (PCR), multiplex PCR and real-time quantitative PCR (qPCR), which have been used for rapid and reliable detection of foodborne pathogens (Chiang et al., 2012). In addition, typifying methods are also largely used for accurate genetic characterization in outbreak investigations. Table 2 shows the molecular genetic 
Table 2. Selection of molecular genetic techniques used for foodborne detection

\begin{tabular}{|c|c|c|c|c|c|}
\hline Bacteria & Approach & $\begin{array}{l}\text { Target gene or } \\
\text { enzyme used }\end{array}$ & Detection & Dairy product & Reference \\
\hline \multirow[t]{7}{*}{$\begin{array}{l}\text { Listeria } \\
\text { monocytogenes }\end{array}$} & qPCR & hly & $4 \log \mathrm{CFU} \mathrm{mL} \mathrm{m}^{-1}$ & $\begin{array}{l}\text { Raw milk, } \\
\text { pasteurized milk, } \\
\text { kulfi, ice cream, } \\
\text { paneer, and infant } \\
\text { foods }\end{array}$ & Singh et al., 2011 \\
\hline & $\mathrm{qPCR}$ & hlyA & $3.63 \log$ & Raw milk & Quero et al., 2013 \\
\hline & $\mathrm{qPCR}$ & hlyA & $\begin{array}{c}\mathrm{CFU} \mathrm{g}^{-1} \\
4.9 \times 10^{3} \mathrm{CFU} \mathrm{g}^{-1}\end{array}$ & Milk & Paul et al., 2015 \\
\hline & Multiplex PCR & htpG & $1 \mathrm{CFU} \mathrm{mL} \mathrm{m}^{-1}$ & Quargel chesse & $\begin{array}{l}\text { Chiang et al., } \\
\quad 2012\end{array}$ \\
\hline & PFGE & AscI and ApaI & $\mathrm{N} \times 10^{4} \mathrm{CFU} \mathrm{ml}{ }^{-1}$ & $\begin{array}{c}\text { Cheese } \\
\text { (pasteurized milk) }\end{array}$ & $\begin{array}{c}\text { Schoder et al., } \\
2014\end{array}$ \\
\hline & PFGE & AscI & & $\begin{array}{c}\text { Cheese } \\
\text { (pasteurized milk) }\end{array}$ & Koch et al., 2010 \\
\hline & PFGE & AscI and ApaI & & & Gaulin et al., 2012 \\
\hline \multirow[t]{6}{*}{ Salmonella } & $\mathrm{qPCR}$ & invA & $3 \log \mathrm{CFU} \mathrm{mL} \mathrm{L}^{-1}$ & $\begin{array}{c}\text { Raw milk, } \\
\text { pasteurized milk, } \\
\text { kulfi, ice cream, } \\
\text { paneer, and infant } \\
\text { foods }\end{array}$ & Singh et al., 2011 \\
\hline & Multiplex PCR & $\begin{array}{l}\text { Random DNA } \\
\text { fragment }\end{array}$ & $\mathrm{N} \times 10^{4} \mathrm{CFU} \mathrm{mL}-1$ & Milk & $\begin{array}{l}\text { Chiang et al., } \\
2012\end{array}$ \\
\hline & $\mathrm{qPCR}$ & Stn & 25 to 500 cells & Milk & $\begin{array}{l}\text { Riyaz-Ul-Hassan } \\
\text { et al., } 2013\end{array}$ \\
\hline & MLVA & - & - & Cheese (raw milk) & $\begin{array}{l}\text { Vignaud et al., } \\
2017\end{array}$ \\
\hline & PCR & $\begin{array}{c}\text { Salmonella } \\
\text { Enteritidis and } \\
\text { Typhimurium }\end{array}$ & $\begin{array}{c}3,03 \% \text { of samples } \\
1 \% \text { of samples }\end{array}$ & $\begin{array}{c}\text { Milk } \\
\text { Cheese (raw milk) }\end{array}$ & $\begin{array}{c}\text { Ahmed and } \\
\text { Shimamoto, } 2014\end{array}$ \\
\hline & PCR & hilA & $\begin{array}{c}5 \text { bacteria } \mathrm{ml}^{-1} \\
10^{3} \text { bacteria } \mathrm{ml}^{-1}\end{array}$ & $\begin{array}{c}\text { Milk } \\
\text { Ice-cream }\end{array}$ & $\begin{array}{l}\text { Marathe et al., } \\
\quad 2012\end{array}$ \\
\hline \multirow[t]{2}{*}{$\begin{array}{l}\text { Staphylococcus } \\
\text { aureus }\end{array}$} & $\mathrm{qPCR}$ & egc & $\begin{array}{c}10^{2} \text { to } 10^{3} \mathrm{CFU} \\
\mathrm{mL}^{-1}\end{array}$ & Raw milk & $\begin{array}{l}\text { Fusco and Quero, } \\
2014\end{array}$ \\
\hline & Multiplex PCR & hsp & $\mathrm{N} \times 10^{4} \mathrm{CFU} \mathrm{ml}{ }^{-1}$ & Milk & $\begin{array}{l}\text { Chiang et al., } \\
2012\end{array}$ \\
\hline E. coli O157 & $\mathrm{qPCR}$ & $\mathrm{Rfb}$ & $1 \mathrm{CFU} \mathrm{mL} \mathrm{mL}^{-1}$ & Raw milk & Paul et al., 2013 \\
\hline E. coli O157: H7 & Multiplex PCR & $\begin{array}{l}\text { Random DNA } \\
\text { fragment }\end{array}$ & $\mathrm{N} \times 10^{4} \mathrm{CFU} \mathrm{mL}^{-1}$ & Milk & $\begin{array}{l}\text { Chiang et al., } \\
\quad 2012\end{array}$ \\
\hline E. coli O157: H7 & $\mathrm{qPCR}$ & $\begin{array}{l}\text { stx } 1, \text { stx2 and } \\
\text { stx2f }\end{array}$ & $\begin{array}{c}4 \times 10^{6} \text { to } 40 \mathrm{CFU} \\
\mathrm{mL}^{-1}\end{array}$ & Milk & $\begin{array}{l}\text { Derzelle } \text { et al. } \\
2011\end{array}$ \\
\hline E. coli O157:H7 & PCR & stx 1, stx 2 and rfb & $\begin{array}{l}2,5 \% \text { of samples } \\
1,1 \% \text { of samples }\end{array}$ & $\begin{array}{l}\text { Raw milk } \\
\text { Cheese }\end{array}$ & $\begin{array}{c}\text { Ahmed and } \\
\text { Shimamoto, } 2014\end{array}$ \\
\hline E. coli $\mathrm{O} 157$ & WGS & - & - & Raw milk & Butcher et al., 2016 \\
\hline
\end{tabular}

qPCR: Quantitative polymerase chain reaction

PFGE: Pulsed field gel electrophoresis

MLVA: Multiple-locus variable-number tandem repeat analysis

PCR: Polymerase chain reaction

WGS: Whole genome sequencing 
techniques applied to dairy products to detect and identify foodborne bacteria.

Molecular techniques for pathogens are being developed for various aspects of detection, such as sensitivity, rapidity, and selectivity (Zhao et al., 2014). Studies have shown that identification systems based on molecular genetic techniques are more discriminating than phenotypic methods and often provide more accurate taxonomic information about a particular strain, which is very important in pathogen surveillance (Henri et al., 2016). Additionally, these approaches allow the detection of very low numbers of organisms in the sample and high throughput of many samples for routine analysis (Lee et al., 2015).

One of the advantages of DNA-based pathogen detection assays is the high level of specificity, as they detect specific nucleic acid sequences in the target organism by hybridizing them to a short synthetic oligonucleotide complementary to the specific nucleic acid sequence (Zhao et al., 2014). These methods have also become valuable tools for investigating foodborne outbreaks and identifying the responsible etiological agents (Riyaz-Ul-Hassan et al., 2013).

\section{Polymerase chain reaction}

PCR is a technique that amplifies a specific DNA sequence, producing thousands to millions of copies. These methods usually detect specific genes in strains of bacteria isolated from contaminated foods (Hennekinne et al., 2012). This technique has been recognized as one of the most promising rapid microbiological methods for the detection and identification of bacteria in a wide range of foods (Auvolat and Besse, 2016). It has been used to detect foodborne bacterial pathogens such as viable Escherichia coli O157:H7, Salmonella and L. monocytogenes in food (Lee et al., 2015; Wang et al., 2015). PCR is widely used to detect Staphylococcus aureus (Kim et al., 2001; Vancraeynest et al., 2007; Yang et al., 2007) because of its high sensitivity and specificity (Chen et al., 2015).

It is important to consider that $\mathrm{PCR}$ requires precise and expensive instruments, and macromolecules such as proteins and fat present in milk and ice cream could interfere with the PCR assay. Removal of these macromolecules is essential to prevent PCR inhibition (Marathe et al., 2012).

\section{Real-time quantitative PCR ( $q P C R$ )}

The use of qPCR has provided several advantages over conventional PCR such as quantification, real-time and in situ analyses, in addition to automation (Riyaz-Ul-Hassan et al., 2013). In this technique, the PCR products are detected as they accumulate. The amount of generated PCR product is proportional to the increase in a fluorescent signal, which is monitored during the exponential phase (Auvolat and Besse, 2016). This technique permits rapid identification and quantification of bacteria (Singh et al., 2011; Quigley et al., 2013).

Several attempts have been made to develop qPCR assays for the detection of L. monocytogenes and Salmonella spp. over a wide range of food products including beef, seafood, fresh produce, and dairy products (Singh et al., 2011). The sensitivity of qPCR when applied to a food matrix is generally quite limited when compared with other enumeration methods. Consequently, in most cases, qPCR is not suitable for the accurate enumeration of, for example, low levels of L. monocytogenes in food (Auvolat and Besse, 2016).

\section{Multiplex PCR}

Multiplex PCR involves the simultaneous detection or amplification of multiple target sequences in a single reaction by using different primers for each target. Multiplex PCR has the potential to produce 
considerable savings of time and effort within the laboratory without compromising test utility (Elnifro et al., 2000).

\section{DNA microarray}

In DNA arrays, specific DNA sequences are synthesized in a 2-D or 3-D array on a surface to which the DNA is covalently or non-covalently attached. The DNA array is used to probe a solution containing a mixture of labeled nucleic acids, and the binding (by hybridization) of these "targets" to the "probes" on the array allows the measurement of the relative concentrations of the nucleic acid in the sample (Bumgarner, 2013). Biochips may allow the simultaneous detection and identification of multiple microorganisms in a relatively short time, and they are being described as a powerful tool for the detection of foodborne pathogens (Chiang et al., 2012). However, the high cost associated with this approach is the main restriction limiting its application in the dairy and food industries on a routine basis (Singh et al., 2011).

\section{Molecular subtyping methods}

Molecular subtyping has been an instrumental tool for the surveillance and outbreak investigation of foodborne illness for several years (Deng et al., 2016) and has proven critical for identifying clusters that warrant further investigation (Jackson et al., 2016). These approaches are essential epidemiological tools for detecting the outbreak of foodborne diseases, and must provide strong discriminatory power and high epidemiological concordance (Liu et al., 2016). The molecular typing methods that are commonly used to detect bacterial disease outbreaks include pulsed field gel electrophoresis (PFGE), multiple-locus variable-number tandem repeat analysis (MLVA), and clustered regularly interspaced short palindromic repeat and multiple-virulence-locus sequence typing (CRISPR-MVLST) (Liu et al., 2016). Recently, these have been powered by whole-genomesequencing (WGS) technologies.

\section{Pulsed field gel electrophoresis}

PFGE has been described as the gold standard for subtyping the genus and species to provide further discrimination among bacterial pathogens (Wuyts et al., 2013; Taylor et al., 2015; Adkins et al., 2016) and is used by the National Molecular Subtyping Network for Foodborne Disease Surveillance in United States (PulseNet) (Bopp et al., 2016). Initially, PFGE was used to type Escherichia coli O157:H7 and then was developed to enable typing of various important bacteria, such as Listeria monocytogenes, Vibrio parahaemolyticus and Salmonella (Liu et al., 2016).

This is the most commonly used molecular subtyping method for surveillance and outbreak detection because of its high discriminatory power and reproducibility (Deng et al., 2016). PFGE was used for the molecular subtyping of Listeria monocytogenes isolates in a commercial cheese made from pasteurized milk that caused an outbreak in Germany from October 2006 through February 2007 (Koch et al., 2010) and in Quebec, Canada, in 2008 (Gaulin et al., 2012). Additionally, in 2010, this technique was useful in determining the genotypic diversity of Listeria monocytogenes in the acid curd cheese that caused a multinational outbreak between 2009 and 2010 (Schoder et al., 2014).

However, PFGE is time-consuming and laborious to perform (Liu et al., 2016), which makes it less suitable for typing many isolates, and it requires rigorous standardization of the protocols (Bertrand et al. 2015). PFGE also lacks the discriminatory capacity and phylogenetic basis of more advanced methods (Jackson et al., 2016). 
Multiple-locus variable-number tandem repeat analysis

MLVA is a molecular subtyping method based on amplification and fragment size analysis of the number of repeats in the variable-number tandem repeats region of the bacterial genome (Bertrand et al. 2015). It is rapid and highly reproducible, and the results are easily interpreted and standardized among laboratories. Bacteria that have been typed by MLVA include Salmonella (Wuyts et al., 2013), Escherichia coli and Vibrio parahaemolyticus (Liu et al., 2016).

This method has proven very useful in investigating foodborne outbreaks because it utilizes the naturally occurring variation in the number of tandem repeat DNA sequences, and it has facilitated analysis since it requires no specific technical expertise (Vignaud et al., 2017). MLVA was applied to a raw milk cheese outbreak in France in 2012 to subtype Salmonella enterica subspecies enterica serovar Dublin, which is one of the most frequently isolated Salmonella strains in humans in that country (Vignaud et al., 2017).

\section{Whole genome sequencing}

PFGE and MLVA often do not provide sufficient resolution to differentiate between outbreaks (Taylor et al., 2015). Recently, whole genome sequencing has offered that discriminatory power with the potential to enhance epidemiological investigations and elucidate transmission pathways (Phillips et al., 2016). The use of next-generation sequencing technology for WGS allows for the sequencing of large numbers of isolates, and novel bioinformatics tools can be used for comparative genomics and analysis of the phylogeny of the isolates (Revez et al., 2014). WGS has been a very useful and powerful tool for establishing potential links between clinical, food and environmental isolates of pathogens, which could allow the identification of the source of contamination and remove contaminated foods from markets (Deng et al., 2016).

WGS has been recently used to understand outbreak sources and the transmission patterns of bacteria, including Escherichia coli, Campylobacter, Listeria spp. and Salmonella spp. (Lambert et al., 2015; Clark et al., 2016; Jackson et al., 2016; Wilson et al., 2016). Furthermore, WGS has the potential to discriminate between sporadic and outbreak isolates which may be indistinguishable by current methods of subtyping (Phillips et al., 2016). WGS usefulness in food safety is undeniable; however, this approach is expensive and is not currently in place in the majority of public health laboratories (Bopp et al., 2016). Additionally, analysis of WGS data can be difficult due to the extensive computational capacity and bioinformatics skills needed for genomic comparisons and to determine a threshold to establish relatedness (Burall et al., 2016).

\section{General remarks}

There are different examples of outbreaks associated with the consumption of dairy products, and the identification of causative bacteria is very complex. Novel molecular techniques have been crucial for accuracy in the detection of foodborne bacteria in diverse types of dairy products (including pasteurized milk), and it is probable that without these molecular approaches, the outbreaks' etiological agents would not have been correctly identified.

On the other hand, the dairy industry requires fast, sensitive and cost-effective technology for the detection of foodborne pathogens in order to fulfill food safety requirements and to establish routine quality control testing. For example, due to the increasing demand for raw products and the conditions (i.e., transport temperature and humidity) between the processing and storing of dairy products, the application of advanced analytical 
methods for pathogen detection could ensure safety and prevent outbreaks due to consumption of contaminated products, reducing the economic losses related to removal of products, negative corporate images and court costs.

Molecular typifying methods are powerful tools for accurate genetic characterization of foodborne pathogens, and the dairy industry and governments might apply them extensively, implementing standard protocols for foodborne pathogens in developed and developing countries, ensuring the food safety of dairy products regardless of their origin. Molecular techniques can be used in different industries such as food and pharmaceutics; however, they require expensive equipment and reagents, and their setup requires highly technical skills. Additionally, infrastructure will be another important factor to consider, since most of these techniques require controlled environments to avoid contamination and misleading results. In the case of the dairy industry, qPCR and PCR techniques are more feasible to implement since they are quick and cost-effective and do not require much skill to perform, compared to other molecular techniques.

\title{
Resumen
}

\begin{abstract}
N. Cancino-Padilla, M. A. Fellenberg, W. Franco, R.A. Ibañez, y E. Vargas-Bello-Pérez. 2017. Bacterias transmitidas por los alimentos en los productos lácteos: detección por técnicas moleculares. Cien. Inv. Agr. 44(3): 215-229. Debido a su composición y propiedades únicas, la leche y los productos lácteos representan un gran medio de crecimiento para muchos microorganismos patógenos. Staphylococcus aureus, Salmonella spp., Listeria monocytogenes y Escherichia coli O157: H7 son los patógenos más frecuentes asociados con la leche o los productos lácteos en los países industrializados. La identificación de estos patógenos a través de métodos tradicionales o dependiente de cultivo requieren mucho tiempo, por lo cual diferentes investigaciones han centrado sus esfuerzos en el desarrollo de métodos de detección rápida para identificar bacterias transmitidas por los alimentos. Conocer el método más apropiado para la identificación de patógenos podría ser útil para la vigilancia y el control de brotes, y también para mejorar las normas de higiene en las prácticas alimentarias con el objetivo de minimizar la contaminación microbiológica.
\end{abstract}

Palabras clave: Inocuidad de alimentos, microbiología, patógenos trasmitidos por los alimentos, técnicas biotecnológicas.

\section{References}

Adkins, P.R., J.R. Middleton, and L.K. Fox. 2016. Comparison of Virulence Gene Identification, Ribosomal Spacer PCR, and Pulsed-Field Gel Electrophoresis for Typing of Staphylococcus aureus Strains Isolated from Cases of Subclinical Bovine Mastitis in the United States. J Clin Microbiol. 54(7):1871-1876.

Ahmed, R., G. Soule, W.H. Demczuk, C. Clark, R. Khakhria, and S. Ratnam, 2000. Epidemiologic Typing of Salmonella enterica Serotype Enteriti- dis in a Canada-Wide Outbreak of Gastroenteritis due to Contaminated Cheese. J Clin Microbiol. 38(6):2403-2406.

Ahmed, A.M. and T. Shimamoto. 2014. Isolation and molecular characterization of Salmonella enterica, Escherichia coli O157:H7 and Shigella spp. from meat and dairy products in Egypt. Int $\mathrm{J}$ Food Microbiol. 168-169:57-62.

Arqués, J.L., E. Rodríguez, S. Langa, J.M. Landete, and M. Medina. 2015. Antimicrobial Activity of Lactic Acid Bacteria in Dairy Products and Gut: Effect on Pathogens. BioMed Research International. 2015:1-9. 
Asao, T., Y. Kumeda, T. Kawai, T. Shibata, H. Oda, and K. Haruki. 2003. An extensive outbreak of staphylococcal food poisoning due to lowfat milk in Japan: estimation of enterotoxin A in the incriminated milk and powdered skim milk. Epidemiol Infect. 130(1):33-40.

Auvolat, A. and N.G. Besse. 2016. The challenge of enumerating Listeria monocytogenes in food. Food Microbiol. 53:135-149.

Bertrand, S., G. De Lamine de Bex, C. Wildemauwe, O. Lunguya, M.F. Phoba, and B. Ley. 2015. Multi Locus Variable-Number Tandem Repeat (MLVA) Typing Tools Improved the Surveillance of Salmonella Enteritidis: A 6 Years Retrospective Study. PLoS ONE. 10(2):e0117950

Bianchi, D.M., A. Barbaro, S. Gallina, N. Vitale, L. Chiavacci, and M. Caramelli. 2013. Monitoring of foodborne pathogenic bacteria in vending machine raw milk in Piedmont, Italy. Food Control. 32:435-439.

Bopp, D.J., D. Baker, L. Thompson, A. Saylors, T.P. Root, and L. Armstrong. 2016. Implementation of Salmonella serotype determination using pulsed-field gel electrophoresis in a state public health laboratory. Diagn Microbiol Infect Dis. $85: 416-418$

Brouard, C., E. Espié, F.X. Weill, A. Kérouanton, A. Brisabois, and A.M. Forgue. 2007. Two consecutive large outbreaks of Salmonella enterica serotype Agona infections in infants linked to the consumption of powdered infant formula. Pediatr Infect Dis J. 26(2):148-52.

Burall, L.S., C.J. Grim, M.K. Mammel, and A.R. Datta 2016. Whole Genome Sequence Analysis Using Species Tool Establishes Clonal Relationships between Listeria monocytogenes Strains from Epidemiologically Unrelated Listeriosis Outbreaks. PLoS ONE. 11(3):e0150797

Butcher, H., R. Elson, M.A. Chattaway, C.A. Featherstone, C. Willis, and F. Jorgensen. 2016. Whole genome sequencing improved case ascertainment in an outbreak of Shiga toxin-producing Escherichia coli $\mathrm{O} 157$ associated with raw drinking milk. Epidemiol Infect. 144(13):2812-23.

Chen, X., X. Wu, M. Gan, F. Xu, L. He and D. Yang. 2015. Rapid detection of Staphylococcus aureus in dairy and meat foods by combination of capture with silica-coated magnetic nanoparticles and thermophilic helicase-dependent isothermal amplification. J Dairy Sci. 98:1563-1570.

Chiang, Y.C., H.Y. Tsen, H.Y. Chen, Y.H. Chang, C.K. Lin and C.Y. Chen. 2012. Multiplex PCR and a chromogenic DNA macroarray for the detection of Listeria monocytogens, Staphylococcus aureus, Streptococcus agalactiae, Enterobacter sakazakii, Escherichia coli O157:H7, Vibrio parahaemolyticus, Salmonella spp. and Pseudomonas fluorescens in milk and meat samples. J Microbiol Methods. 88:110-116.

Claeys, W.L., S. Cardoen, G. Daube, J. De Block, K. Dewettinck and K. Dierick, 2013. Raw or heated cow milk consumption: Review of risks and benefits. Food Control 31: 251e262.

Clark, C.G., C. Berry, M. Walker, A. Petkau, D.O. Barker and C. Guan. 2016. Genomic insights from whole genome sequencing of four clonal outbreak Campylobacter jejuni assessed within the global C. jejuni population. BMC Genomics 17:990.

Dalzini, E., V. Bernini, B. Bertasi, P. Daminelli, M.N. Losio and G. Varisco. 2016. Survey of prevalence and seasonal variability of Listeria monocytogenes in raw cow milk from Northern Italy. Food Control. 60:466-470.

De Castro, V., J. Escudero, J. Rodriguez, N. Muniozguren, J. Uribarri and D. Saez. 2012. Listeriosis outbreak caused by Latin-style fresh cheese, Bizkaia, Spain, August 2012. Euro Surveill. 17(42):20298.

Deng, X., H.C. den Bakker and R.S. Hendriksen. 2016. Genomic Epidemiology: Whole-GenomeSequencing-Powered Surveillance and Outbreak Investigation of Foodborne Bacterial Pathogens. Annu Rev Food Sci Technol. 7:353-74.

Denny, J., M. Bhat and K. Eckmann. 2008. Outbreak of Escherichia coli O157:H7 Associated with Raw Milk Consumption in the Pacific Northwest. Foodborne Pathog Dis. 5:321-328.

Derzelle, S., A. Grine, J. Madic, C.P. de Garam, N. Vingadassalon and F. Dilasser. 2011. A quantitative PCR assay for the detection and quantification of Shiga toxin-producing Escherichia coli 
(STEC) in minced beef and dairy products. Int $\mathrm{J}$ Food Microbiol. 151(1):44-51.

De Valk, H., E. Delarocque-Astagneau, G. Colomb, S. Ple, E. Godard and V. Vaillant. 2000. A community--wide outbreak of Salmonella enterica serotype Typhimurium infection associated with eating a raw milk soft cheese in France. Epidemiol Infect. 124(1):1-7.

Dominguez, M., N. Jourdan-Da Silva, V. Vaillant, N. Pihier, C. Kermin and F.X. Weill. 2009. Outbreak of Salmonella enterica serotype Montevideo infections in France linked to consumption of cheese made from raw milk. Foodborne Pathog Dis. 6(1):121-128.

Duquenne, M., I. Fleurot, M. Aigle, C. Darrigo, E. Borezée-Durant and S. Derzelle. 2010. Tool for Quantification of Staphylococcal Enterotoxin Gene Expression in Cheese. Appl Environ Microbiol. 76(5):1367-1374.

Fetsch, A., M. Contzen, K. Hartelt, A. Kleiser, S. Maassen and J. Rau. 2014. Staphylococcus aureus food-poisoning outbreak associated with the consumption of ice-cream. Int J Food Microbiol. 187:1-6.

Fretz, R., J. Pichler, U. Sagel, P. Much, W. Ruppitsch and A.T. Pietzka. 2010. Update: Multinational listeriosis outbreak due to 'Quargel', a sour milk curd cheese, caused by two different L. monocytogenes serotype 1/2a strains, 2009-2010. Euro Surveill. 15(16): 19543.

Fusco, V. and G.M. Quero. 2014. Culture-Dependent and Culture-Independent Nucleic-AcidBased Methods Used in the Microbial Safety Assessment of Milk and Dairy Products. Compr Rev Food Sci Food Saf. 13:493-537.

Gaulin, C., D. Ramsay and S. Bekal. 2012. Widespread listeriosis outbreak attributable to pasteurized cheese, which led to extensive crosscontamination affecting cheese retailers, Quebec, Canada, 2008. J Food Prot. 75(1):71-78.

Giacometti, J., A. Buretić Tomljanović and D. Josić. 2013. Application of proteomics and metabolomics for investigation of food toxins. Food Res Int. 54:1042-1051.

Gill, A. and D. Oudit. 2015. Enumeration of Escherichia coli O157 in Outbreak-Associated Gou- da Cheese Made with Raw Milk. J Food Prot. 78(9):1733-1737.

Gould, L.H., E. Mungai and C.B. Behravesh. 2014. Outbreaks attributed to cheese: differences between outbreaks caused by unpasteurized and pasteurized dairy products, United States, 19982011. Foodborne Pathog Dis.11:545-551.

Heiman, K.E., V.B. Garalde, M. Gronostaj, K.A. Jackson, S. Beam and L. Joseph. 2016. Multistate outbreak of listeriosis caused by imported cheese and evidence of cross-contamination of other cheeses, USA, 2012. Epidemiol Infect. 144(13):2698-2708.

Hennekinne, J., M. De Buyser and S. Dragacci. 2012. Staphylococcus aureus and its food poisoning toxins: characterization and outbreak investigation. FEMS Microbiol Rev. 36:815-836.

Henri, C., B. Félix, L. Guillier, P. Leekitcharoenphon, D. Michelon and J. Mariet. 2016. Population Genetic Structure of Listeria monocytogenes Strains as Determined by Pulsed-Field Gel Electrophoresis and Multilocus Sequence Typing. Appl Environ Microbiol. 82: 5720-5728.

Heuvelink, A.E., C. van Heerwaarden, A. Zwartkruis-Nahuis, J.J. Tilburg, M.H. Bos, F.G. and Heilmann. 2009. Two outbreaks of campylobacteriosis associated with the consumption of raw cows' milk. Int J Food Microbiol.134(1-2):70-74.

Jackson BR, Tarr C, Strain E, Jackson KA, Conrad A, Carleton H, L.S.Katz, S. Stroika, L.H.Gould, R.K. Mody, B.J. Silk, J. Beal, Y. Chen, R. Timme, M. Doyle, A. Fields, M. Wise, G. Tillman, S. Defibaugh-Chavez, Z. Kucerova, A. Sabol, K. Roache, E. Trees, M. Simmons, J. Wasilenko, K. Kubota, H. Pouseele, W. Klimke, J. Besser, E. Brown, M. Allard and P. Gerner-Smidt. 2016. Implementation of Nationwide Real-time Whole-genome Sequencing to Enhance Listeriosis Outbreak Detection and Investigation. Clin Infect Dis. 63(3):380-386.

Jakobsen, R.A., R. Heggebø, E.B. Sunde and M. Skjervheim. 2011. Staphylococcus aureus and Listeria monocytogenes in Norwegian raw milk cheese production. Food Microbiology. 28:492-496.

Johler, S., D. Weder, C. Bridy, M.C. Huguenin, L. Robert and J. Hummerjohann. 2015. Outbreak 
of staphylococcal food poisoning among children and staff at a Swiss boarding school due to soft cheese made from raw milk. J Dairy Sci. 98(5):2944-2948.

Kérouanton, A., J.A. Hennekinne, C. Letertre, L. Petit, O. Chesneau and A. Brisabois. 2007. Characterization of Staphylococcus aureus strains associated with food poisoning outbreaks in France. Int J Food Microbiol. 115(3):369-75.

Koch, J., R. Dworak, R. Prager, B. Becker, S. Brockmann and A Wicke. 2010. Large Listeriosis Outbreak Linked to Cheese Made from Pasteurized Milk, Germany, 2006-2007. Foodborne Pathog Dis.7(12):1581-1584.

Kousta, M., M. Mataragas, P. Skandamis and H. Drosinos. 2010. Prevalence and sources of cheese contamination with pathogens at farm and processing levels. Food Control. 21:805-815.

Lambert, D., C.D. Carrillo, A.G. Koziol, P. Manninger and B.W. Blais. 2015. GeneSippr: A Rapid Whole-Genome Approach for the Identification and Characterization of Foodborne Pathogens such as Priority Shiga Toxigenic Escherichia coli. PLoS One. 10(4):e0122928.

Lee, K., M. Runyon, T.J. Herrman, R. Phillips and J. Hsieh. 2015. Review of Salmonella detection and identification methods: Aspects of rapid emergency response and food safety. Food Control. 47:264-276.

Liu, Y., X. Shi, Y. Li, Q. Chen, M. Jiang, W. Li, Y. Qiu, Y. Lin, Y. Jiang, B. Kan, Q. Sun and Q. Hu. 2016. The evaluation and application of multilocus variable number tandem repeat analysis (MLVA) for the molecular epidemiological study of Salmonella enterica subsp. enterica serovar Enteritidis infection. Ann Clin Microbiol Antimicrob. 15:4.

López, C., A. Feltri, G. Leotta, G. González, E. Manfredi, G. Gottardi, M. Elder, S. De Las Carreras, C. Patri, F. Guajardo, A. San Martín and M. Rivas. 2008. Brote de enfermedad alimentaria en la localidad de El Huecú, provincia de Neuquén. Rev argent microbiol. 40(4):198-203.

Lyytikäinen, O., T. Autio, R. Maijala, P. Ruutu, T. Honkanen-Buzalski, M. Miettinen, M. Hatakka, J. Mikkola, V.J. Anttila, T. Johansson, L. Ranta- la, T. Aalto, H. Korkeala, A. and Siitonen. 2000. An outbreak of Listeria monocytogenes serotype 3a infections from butter in Finland. J Infect Dis. 181(5):1838-1841.

Marathe, S.A., R. Chowdhury, R. Bhattacharya, A.G. Nagarajan and D. Chakravortty. 2012. Direct detection of Salmonella without pre-enrichment in milk, ice-cream and fruit juice by PCR against hilA gene. Food Control. 2012;23:559-563.

Melo, J., P.W. Andrew and M.L. Faleiro. 2015. Listeria monocytogenes in cheese and the dairy environment remains a food safety challenge: The role of stress responses. Food Res Int. 67: 75-90.

McCollum, J.T., N.J. Williams, S.W. Beam, S. Cosgrove, P.J. Ettestad, T.S. Ghosh, A.C. Kimura, L. Nguyen, S.G. Stroika, R.L. Vogt, A.K. Watkins, J.R. Weiss, I.T. Williams and A.B. Cronquist. 2012. Multistate Outbreak of Escherichia coli O157:H7 Infections Associated with In-Store Sampling of an Aged Raw-Milk Gouda Cheese, 2010. J Food Prot. 75:1759-1765.

McIntyre, L., L. Wilcott and M. Naus. 2015. Listeriosis Outbreaks in British Columbia, Canada, Caused by Soft Ripened Cheese Contaminated from Environmental Sources. BioMed Res Int. 1-12.

MMWR. Outbreak of Multidrug-Resistant Salmonella enterica Serotype Newport Infections Associated With Consumption of Unpasteurized Mexican-Style Aged Cheese-Illinois, March 2006-April 2007. JAMA. 2008;299:2850-2851.

Montero, D., M. Bodero, G. Riveros, L. Lapierre, A. Gaggero, R.M. Vidal and M. Vidal. 2015. Molecular epidemiology and genetic diversity of Listeria monocytogenes isolates from a wide variety of ready-to-eat foods and their relationship to clinical strains from listeriosis outbreaks in Chile. Front Microbiol. 6:384.

Mungai, E.A., B.C. Barton and L.H. Gould. 2015. Increased Outbreaks Associated with Nonpasteurized Milk, United States, 2007-2012. Emerg Infect Dis. 21:119-122.

Nada, S.D., T. Igor, M. Jelena and G. Ruzica. 2012. Implication of food safety measures on microbiological quality of raw and pasteurized milk. Food Control. 25:728-731. 
Ostyn, A., M.L. De Buyser, F. Guillier, J. Groult, B. Felix, S. Salah, G. Delmas, J.A. Hennekinne. 2010. First evidence of a food poisoning outbreak due to staphylococcal enterotoxin type E, France, 2009. Euro Surveill. 15(13):19528.

Pärn, T., S. Hallanvuo, S. Salmenlinna, A. Pihlajasaari, S. Heikkinen, H. Telkki-Nykänen, J. Ollgren, S. Huusko, R. Rimhanen-Finne. 2015. Outbreak of Yersinia pseudotuberculosis O:1 infection associated with raw milk consumption, Finland, spring 2014. Euro Surveill. 20(40).

Paul, M., G.M. Baranzoni, S. Albonetti and J.D. Brewster. 2015. Direct, quantitative detection of Listeria monocytogenes in fresh raw whole milk by qPCR. Int Dairy J. 41:46-49.

Phillips, A., C. Sotomayor, Q. Wang, N. Holmes, C. Furlong, K. Ward, P. Howard, S. Octavia, R. Lan, V. Sintchenko. 2016. Whole genome sequencing of Salmonella Typhimurium illuminates distinct outbreaks caused by an endemic multi-locus variable number tandem repeat analysis type in Australia, 2014. BMC Microbiology. 6:211.

Pouillot, R., K.C. Klontz, Y. Chen, L.S. Burall, D. Macarisin, M. Doyle, K.M. Bally, E. Strain, A.R. Datta, T.S. Hammack and J.M. Van Doren. 2016. Infectious Dose of Listeria monocytogenes in Outbreak Linked to Ice Cream, United States, 2015. Emerg Infect Dis. 22(12):2113-2119.

Quero, G.M., E. Santovito, A. Visconti and V. Fusco. 2014. Quantitative detection of Listeria monocytogenes in raw milk and soft cheeses: Cultureindependent versus liquid- and solid-based culture dependent real time PCR approaches. LWT -Food Science and Technology. 58: 11-20.

Quigley, L., R. McCarthy, O. O’Sullivan, T.P. Beresford, G.F. Fitzgerald, R.P. Ross, C. Stanton and P.D. Cotter. 2013. The microbial content of raw and pasteurized cow milk as determined by molecular approaches. J Dairy Sci. 96:4928-4937.

Revez,J., J. Zhang, T. Schott, R. Kivistö, M. Rossi, M.L. 2014. Hänninen. Genomic Variation between Campylobacter jejuni Isolates Associated with Milk-Borne-Disease Outbreaks. J Clin Microbiol. 52(8):2782-6.

Ricci A, Capello K, Cibin V, Pozza G, Ferrè N, Barrucci F, R.Menin, R. Farina, S. Marangon. 2013.
Raw milk-associated foodborne infections: A scoring system for the risk-based categorisation of raw dairy farms. Res Vet Sci. 95:69-75.

Rietberg, K., J. Lloyd, B. Melius, P. Wyman, R. Treadwell, G. Olson, M.G. Kang and J.S. Duchin. 2016. Outbreak of Listeria monocytogenes infections linked to a pasteurized ice cream product served to hospitalized patients. Epidemiol Infect. 144(13):2728-2731.

Riyaz-Ul-Hassan, S., V. Verma and G.N. Qazi. 2013. Real-time PCR-based rapid and culture-independent detection of Salmonella in dairy milk - addressing some core issues. Lett Appl Microbiol. 56:275-282.

Robinson, T.J., J.M. Scheftel and K.E. Smith. 2014. Raw milk consumption among patients with nonoutbreak-related enteric infections, Minnesota, USA, 2001-2010. Emerg Infect Dis. 20(1): 38-44.

Rosengren, Å., A. Fabricius, B. Guss, S. Sylvén and R. Lindqvist. 2010. Occurrence of foodborne pathogens and characterization of Staphylococcus aureus in cheese produced on farm-dairies. Int J Food Microbiol. 144:263-269.

Schmid, D., R. Fretz, P. Winter, M. Mann, G. Höger, A. Stöger, W. Ruppitsch, J. Ladstätter, N. Mayer, A. de Martin and F. Allerberger. 2009. Outbreak of staphylococcal food intoxication after consumption of pasteurized milk products, June 2007, Austria. Wien Klin Wochenschr. 121(34):125-131.

Schoder, D., B. Stessl, K. Szakmary-Brändle, P. Rossmanith and M. Wagner. 2014. Population diversity of Listeria monocytogenes in quargel (acid curd cheese) lots recalled during the multinational listeriosis outbreak 2009/2010. Food Microbiol. 39:68-73.

Singh, J., V.K. Batish and S. Grover. 2011. Molecular beacon based real-time PCR assay for simultaneous detection of Listeria monocytogenes and Salmonella spp. in dairy products. Dairy Sci Technol. 91:373-382.

Tayel, A.A., H. Hussein, N.M. Sorour and W.F. ElTras. 2015. Foodborne Pathogens Prevention and Sensory Attributes Enhancement in Processed Cheese via Flavoring with Plant Extracts. J Food Sci. 80: M2886-M2891. 
Taylor, E.V., K.M. Herman, E.C. Ailes, C. Fitzgerald, J.S. Yoder, B.E. Mahon and R.V. Tauxe. 2013. Common source outbreaks of Campylobacter infection in the USA, 1997-2008. Epidemiol Infect. 141:987-996.

Taylor, A.J., V. Lappi, W.J. Wolfgang, P. Lapierre, M.J. Palumbo, C. Medus and D. Boxrud. 2015. Characterization of foodborne outbreaks of Salmonella enterica serovar Enteritidis with whole-genome sequencing single nucleotide polymorphism-based analysis for surveillance and outbreak detection. J Clin Microbiol. 53: $3334-3340$.

Threlfall, E.J., L.R. Ward, M.D. Hampton, A.M. Ridley, B. Rowe, D. Roberts, R.J. Gilbert, P. Van Someren, P.G. Wall and P. Grimont. 1998. Molecular fingerprinting defines a strain of Salmonella enterica serotype Anatum responsible for an international outbreak associated with formula-dried milk. Epidemiol Infect. 121(2):289-93.

Todd, E.C.D. and S. Notermans. 2011. Surveillance of listeriosis and its causative pathogen, Listeria monocytogenes. Food Control. 22:1484-1490.

Tomat, D., C. Balagué, C. Casabonne, R. Verdini and A. Quiberoni. 2016. Resistance of foodborne pathogen coliphages to additives applied in food manufacture. LWT - Food sci technol. 67: 50-54.

Van Duynhoven, Y.T., L.D. Isken, K. Borgen, M. Besselse, K. Soethoudt, O. Haitsma, B. Mulder, D.W. Notermans, R. De Jonge, P. Kock, W. Van Pelt, O. Stenvers, J. Van Steenbergen. 2009. Outbreak Investigation Team, A prolonged outbreak of Salmonella Typhimurium infection related to an uncommon vehicle: hard cheese made from raw milk. Epidemiol Infect. 137(11):1548-1557.

Verraes, C., G. Vlaemynck, S. Van Weyenberg, L. De Zutter, G. Daube, M. Sindic, et al. M. Uyttendaelec and L.Herman. 2015. A review of the microbiological hazards of dairy products made from raw milk. Int Dairy J. 50:32-44.
Vignaud, M., E. Cherchame, M. Marault, E. Chaing, S. Le Hello, V. Michel, N. Jourdan-Da Silva, R. Lailler, A. Brisabois and S. Cadel-Six. 2017. MLVA for Salmonella enterica subsp. enterica Serovar Dublin: Development of a Method Suitable for Inter-Laboratory Surveillance and Application in the Context of a Raw Milk Cheese Outbreak in France in 2012. Front Microbiol. 8:295.

Wang, J., X. Xie, J. Feng, J.C. Chen, X. Dua, J. Luo, $\mathrm{X}$. $\mathrm{Lu}$ and S. Wang. 2015. Rapid detection of Listeria monocytogenes in milk using confocal micro-Raman spectroscopy and chemometric analysis. Int J Food Microbiol. 204:66-74.

Weiler, N., G.A. Leotta, M.N. Zárate, E. Manfredi, M.E. Álvarez and M. Rivas. 2011. Brote de intoxicación alimentaria asociado al consumo de leche ultrapasteurizada en la República del Paraguay. Rev argent microbiol. 43(1):33-36.

Wuyts, V., W. Mattheus, G. De Laminne de Bex, C. Wildemauwe, N.H. Roosens, K. Marchal, S.C.J. De Keersmaecker and S. Bertrand. 2013. MLVA as a Tool for Public Health Surveillance of Human Salmonella Typhimurium: Prospective Study in Belgium and Evaluation of MLVA Loci Stability. PLoS One. 8(12):e84055.

Yang, B., Y. Shi, X. Xia, M. Xi, X. Wang, B. Ji and J. Meng. 2012. Inactivation of foodborne pathogens in raw milk using high hydrostatic pressure. Food Control. 28:273-278.

Yu, J., Y. Zhang, Y. Zhang, H. Li, H. Yang and H. Wei. 2016. Sensitive and rapid detection of staphylococcus aureus in milk via cell binding domain of lysine. Biosens Bioelectron. 77:366-371.

Zhao, X., C. Lin, J. Wang and Oh.D. Hwan. 2014. Advances in Rapid Detection Methods for Foodborne Pathogens. J Microbiol Biotechnol. 24(3):297-312.

Zhao, X., C. Wei, J. Zhong and S. Jin. 2016. Research advance in rapid detection of foodborne Staphylococcus aureus. Biotechnol Biotechnol Equip. 30:827-833. 